\title{
DEGRADATION OF PEAT SURFACE ON AN ABANDONED POST- EXTRACTED BOG AND IMPLICATIONS FOR RE-VEGETATION
}

\author{
ZAJĄC, E. $^{{ }^{*}}-$ ZARZYCKI, J. $^{2}-$ RYCZEK, $^{\text {M. }}{ }^{1}$ \\ ${ }^{I}$ Department of Land Reclamation and Environmental Development, Faculty of Environmental \\ Engineering and Land Surveying, University of Agriculture, in Krakow, Poland \\ ${ }^{2}$ Department of Ecology, Climatology and Air Protection, Faculty of Environmental \\ Engineering and Land Surveying, University of Agriculture in Krakow, Poland \\ *Corresponding author \\ e-mail:e.zajac@ur.krakow.pl \\ (Received $21^{\text {st }}$ Feb 2018; accepted $24^{\text {th }}$ May 2018)
}

\begin{abstract}
After peat extraction cut-over surface usually consists of moderately to highly humified peat which undergoes secondary transformation due to severely disturbed water conditions. The study was carried out within a mountain bog (Polish Carpathian) located in Orava-Nowy Targ Basin, southern Poland. The objectives of the study was to determine physical, hydrophysical and chemical properties of the upper layer of soil on two post-extracted areas of different age and to identify correlations between hydrophysical parameters and re-vegetation pattern. Vegetation was analysed in two groups: bog forming (Sphagnum, others) and non-bog forming (true mosses, trees, others). Secondary transformation of peat was quantitatively described by water-holding capacity index $\mathrm{W}_{1}$. It correlated with thickness of residual peat and a range of properties of cut-over peat (e.g. porosity, bulk density, soil moisture content, ash content). The Principal Component Analysis (PCA) demonstrated the key importance of water table depth, residual peat thickness and hydrophysical conditions of the cut-over peat, especially water-holding capacity index $\mathrm{W}_{1}$, soil moisture content and macropore volume on re-vegetation by typical bog species. Correlation of $\mathrm{W}_{1}$ index with soil properties and Sphagnum occurrence indicates that it can be a useful indicator in evaluation of secondary transformation of cut-over bogs and therefore the potential for spontaneous regeneration of typical bog vegetation.
\end{abstract}

Keywords: secondary transformation of peat, peat soil properties, water retention, cut-over peatland, peat quality

\section{Introduction}

The European continent experienced the greatest loss of global resources of mires and peatlands, which is estimated at about $52 \%$ of their area (Joosten and Clarke, 2002). Management of peatland has a long tradition in Europe. Peatlands were drained and used mainly as farmlands and forests. Peat has also been extracted for fuel for centuries. In Western Europe its exploitation was the most intense in the 19th century, when mechanized peat extraction was introduced. Since the second half of the 20th century, peat has become an increasingly popular growing media in horticulture, and the most suitable substrate is poorly decomposed raised peat (Ilnicki, 2002). Rapid rate of degradation and disappearance of peatland ecosystems, particularly in Western Europe, encouraged development of a preservation and protection strategy for peatlands of Central Europe where losses have been less severe (Bragg and Lindsey, 2003).

In 2016 in Poland there were 290 peat deposits documented as suitable for peat extraction, of which 83 were still actively extracted and 78 were post-extracted sites (Szuflicki et al., 2017). 
Peat extraction requires drainage and removal of acrotelm, which severely alters natural functions of peatlands e.g. maintaining stable water level (Van Seters and Price, 2001). Peat soil after drainage experience transformation in aerobic conditions which is termed as secondary transformation (e.g. Kalisz et al., 2015). To quantitatively evaluate its state a water-holding capacity index $\mathrm{W}_{1}$ may be used (e.g. Gawlik, 1992). This index expresses as a ratio of the lowest and the highest water-holding capacity of the soil and reflects changes in the physical, hydrophysical and chemical properties of peat soil subject to drying (Gawlik, 2000; Sokołowska et al., 2005).

When the cut-over sites are abandoned without any further treatment, the peat mass undergoes shrinkage, compression, and oxidation collectively known as peat subsidence (e.g. Eggelsmann, 1986). Those processes alter morphology of the soil profile as well as physical, hydrophysical and chemical properties of peat (Ilnicki and Zeit, 2003). As shown in other research (e.g. Schlotzhauer and Price, 1999; Price et al., 2003) increase in soil density after drainage results in pore size reduction, decrease of hydraulic conductivity and specific yield (the capacity of saturated soil to release water from storage by gravity drainage). This, in turn, further causes greater fluctuation of water table (e.g. Schouwenaars, 1993; Whittington and Price, 2006). Changes in pore size distribution trigger alterations in water storage that depends on the size of pores in the zone of water table fluctuation and the corresponding specific yield (Verry et al., 2011). Chemical transformation, mainly mineralization of nitrogen and carbon containing compounds, and composition of organic and inorganic material may change nutrient status of the soil as well as ground water quality (e.g. Wind-Mulder and Vitt, 2000; Laine et al., 2013). Peat oxidation leads to relative enrichment of ash content and to lowering of $\mathrm{C}: \mathrm{N}$ ratio due to a preferential loss of $\mathrm{C}$ over $\mathrm{N}$ resulting from microbial decomposition (Krüger et al., 2015). It also causes substantial emissions of greenhouse gases $\left(\mathrm{CO}_{2}, \mathrm{~N}_{2} \mathrm{O}\right)$, which is a considerable challenge in the context of climatic changes (e.g. Couwenberg, 2011; Hufnagel and Garamvölgyi, 2014).

Considering irreversible changes in peat structure and properties as well as greenhouse gases emission, restoration of post-extracted peatlands should begin right after the cutting is finished (Waddington et al., 2001). The only way to delay these processes is by complete inundation or by re-establishment of peat forming vegetation (Joosten, 1992). Regeneration of typical bog vegetation with Sphagum as a dominant component depends primarily on the hydrophysical conditions of the uppermost peat layer, as they are considered the main factors affecting water table fluctuations and the occurrence of water stress (Schouwenaars and Gosen, 2007).

Due to the history of peatland management in Europe and Poland, many studies on degradation of organic soils concern drained and agriculturally used (grasslands, arable lands) peatlands, especially fens (see Parent and Ilnicki, 2003). There have not been many research on the secondary transformation of soils of post-extracted bogs in Poland. This topic should be definitely focused on, especially in the context of numerous activities aimed at the conservation and restoration of peatlands (e.g. Herbichowa et al., 2007; Okruszko et al., 2011; Glińska-Lewczuk et al., 2014). Currently, degraded peatlands are often near or within various nature protection areas as in the case of the cut-over bog investigated in this study. That is why the assessment of regeneration potential of such sites is particularly important.

The objectives of the presented study were as follows: a) to determine physical, hydrophysical and chemical properties of the upper layer of peat soil on post-extracted areas of different age, b) to identify correlations between hydrophysical parameters of 
cut-over peat surface and re-vegetation pattern. This will expand our knowledge on changes in bog peat undergoing degradation in post-extraction areas. It would be also helpful in selecting soil parameters most strongly affecting the potential of cut-over bogs for restoration of typical bog peat-forming vegetation.

\section{Materials and methods}

\section{Study area}

The study was carried out within a raised bog Bór za Lasem which is located in Orava-Nowy Targ Basin, southern Poland (Fig. 1). It is one of 27 sites that form a complex of mountain peatlands belonging to the European Ecological Network Natura 2000 (PLH120016, PLB120007). Northern and southern borders of the Orava-Nowy Targ Basin are flanked by mountain ranges. It is located within moderately warm climate zone with local peculiarities (Kondracki, 2011). Mean annual air temperature is $5.5^{\circ} \mathrm{C}$ (max: July $16{ }^{\circ} \mathrm{C}$; min: February $-6^{\circ} \mathrm{C}$ ), and annual total precipitation ranges from $750 \mathrm{~mm}$ to $825 \mathrm{~mm}$ (Olszewski, 1988). Basic weather characteristics were also recorded in 2016. Between June and August mean air temperature was $15.4{ }^{\circ} \mathrm{C}$, with a maximum of $37.0^{\circ} \mathrm{C}$ and minimum of $-2.9^{\circ} \mathrm{C}$. Mean precipitation for that period was $375 \mathrm{~mm}$

a)

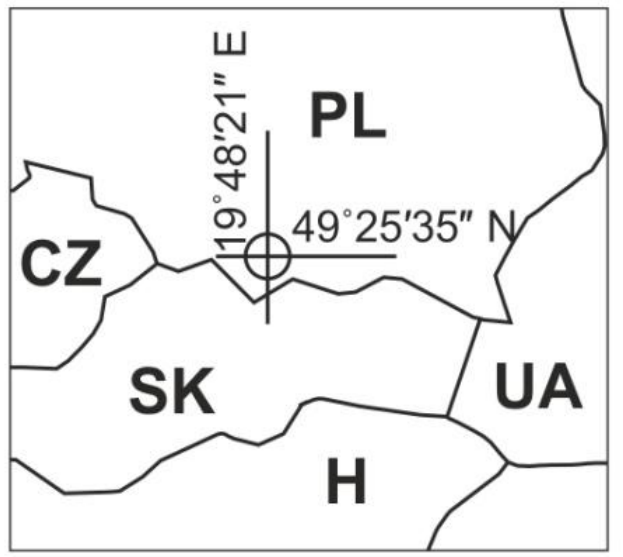

b)

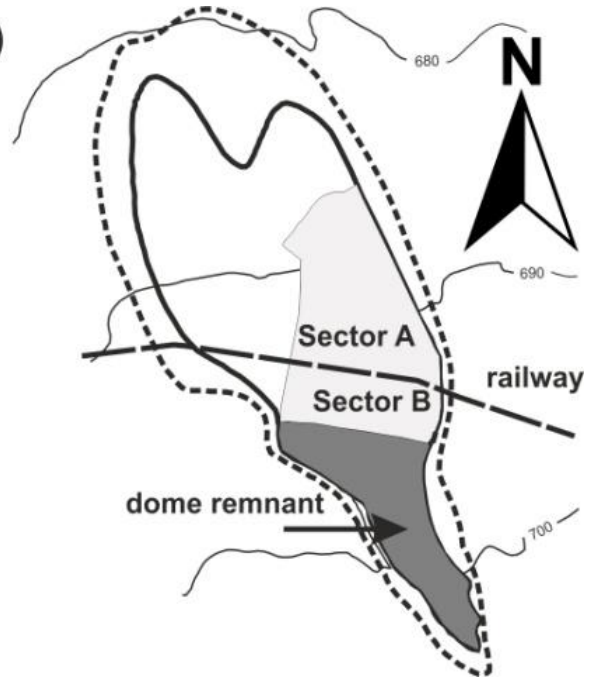

Figure 1. Location of Bór za Lasem peat bog (a) and investigated post-extraction sectors (adapted from Łajczak, 2006) (b)

Bór za Lasem bog was formed as a result of paludification of poorly permeable clay substrate. It is a raised bog but the supply of shallow groundwater was important at the initial stage of its formation. The site is dominated by ombrogenic peats, cotton-grassSphagnum (Eriophoro-Sphagneti) and hummock Sphagnum (Eusphagneti), and locally with poor-fen Sphagnum-sedge (Sphagno-Cariceti) peat and sapric peat at the base. The bog area is $55 \mathrm{ha}$, and mean peat thickness is ca. $1.80 \mathrm{~m}(\max 3.65 \mathrm{~m})$. Mean degree of peat decomposition (determined with microscopic method) in the remaining bog dome is $30 \%$, and mean ash content is $2.2 \%$ (Lipka and Zając, 2014). 
After the Second World War, the bog was extracted within two sectors (Fig. 1), with block-cutting method using heavy machinery. Sector A (ca. 16 ha) was cut-over from the beginning of 1960s until the beginning of 1980s. Then the extraction continued on Sector B (ca. 8 ha) until the beginning of 1990s (personal communication). When the extraction was finished the sites were abandoned (Fig. 2). Both sectors are crossed with a network of secondary drainage ditches spaced at about $20 \mathrm{~m}$ that remove water to main ditches. Most of the secondary ditches are currently filled in and overgrown with vegetation and primary ditches remove water mainly during major floods after precipitation and spring snowmelt.

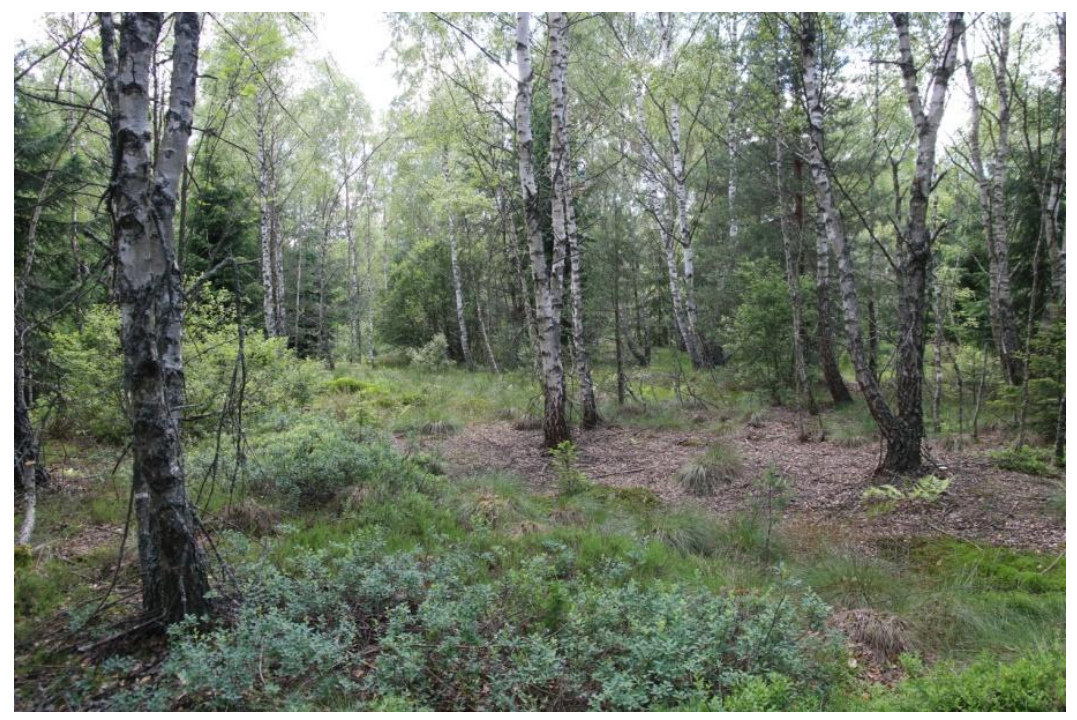

$\mathbf{a}$

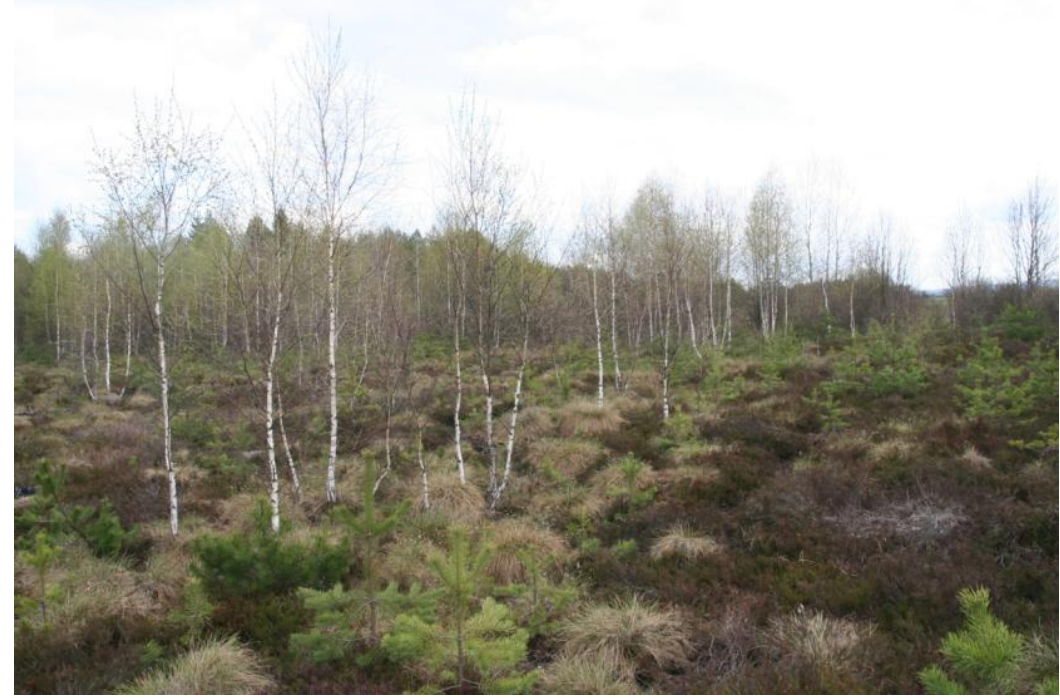

b

Figure 2. General view of the investigated post-extraction Sectors $A(a)$ and B (b) of Bór za Lasem peat bog

Measurements of water level carried out from June to August 2016 in both postextracted sectors in piezometers showed that if the residual peat was ca. $40 \mathrm{~cm}$ and 
less thick the water table dropped 13-22 $\mathrm{cm}$ below the peat layer (recorded for 58\% and $17 \%$ of the plots on Sectors A and B respectively). If peat layer was thicker, mean water level was $25.4 \mathrm{~cm}$ for Sector A and $16.1 \mathrm{~cm}$ for Sector B. Control measurements of groundwater quality were performed twice in the summer in two piezometers from each sector. Mean water $\mathrm{pH}$ were 2.86 and 3.07 and electric conductivity $41 \mu \mathrm{S} \mathrm{cm}^{-1}$ and $50 \mu \mathrm{S} \mathrm{cm}^{-1}$ for Sectors A and B respectively.

\section{Soil analysis}

The study on post-extracted area of Bór za Lasem bog was conducted in the years 2015-2016. Twenty study plots $(5 \mathrm{~m} \times 5 \mathrm{~m}$ each) were laid out on each of the two sectors and they were arranged in W-shaped transects. At each study plot peat thickness was measured with a soil probe and samples for laboratory analysis were taken from two layers: $0-10 \mathrm{~cm}$ (after removing of litter) and 10-20 cm. Soil samples were collected in metal rings (160 rings, $250 \mathrm{~cm}^{3}$ ) and into plastic bags ( 80 samples). Additionally, to determine peat type exposed after extraction, peat matrix samples were collected from eight randomly selected plots from different areas on both sectors (four locations from each sector). All the analyses were performed in duplicate.

The degree of peat decomposition was determined according to Von Post (1924), and peat type with microscopic method based on plant macrofossils composition (Kac et al., 1977; Tobolski, 2000).

The state of secondary transformation of peat was assessed based on physical, hydrophysical and chemical properties comprising: water-holding capacity index $\left(\mathrm{W}_{1}\right)$, dry bulk density $\left(\rho_{\mathrm{b}}\right)$, specific density $(\rho)$, total porosity $(\mathrm{n})$, volumetric moisture content $\left(\theta_{\mathrm{v}}\right)$, saturated moisture content $\left(\theta_{\mathrm{s}}\right)$, volumetric shrinkage $\left(\mathrm{S}_{\mathrm{v}}\right)$, maximum hygroscopic moisture content $(\mathrm{MH})$, water retention curve $(\mathrm{pF})$, ash content $(\mathrm{A}), \mathrm{pH}$, electric conductivity $(\mathrm{EC})$, total carbon $(\mathrm{C})$, total nitrogen $(\mathrm{N})$, mineral nitrogen forms $\left(\mathrm{NO}_{3}{ }^{-}, \mathrm{NH}_{4}{ }^{+}\right)$, and available phosphorus $(\mathrm{P})$.

Bulk density, soil moisture content and volumetric shrinkage were measured in samples of undisturbed structure following sample drying at $105^{\circ} \mathrm{C}$ for to a constant weight. To determine saturated moisture content, soil samples were soaked with water for three weeks before drying. Bulk density and soil moisture content were then calculated with routinely used formulas. Volumetric shrinkage was estimated as a difference in sample volume in saturated and dry state $\left(105^{\circ} \mathrm{C}\right)$ to its volume in saturated state. Specific density was calculated with the formula by Okruszko (1971) based on ash content (see Eq. 1), and total porosity was worked out using specific density and bulk density.

$$
\rho=0.011 \cdot A+1.451
$$

Water-holding capacity index was determined according to the method provided by Gawlik (1992). Each soil sample was divided into two parts. One part at fieldmoisture state was saturated in distilled water for 7 days. The second part was first dried to an absolutely dry weight $\left(105^{\circ} \mathrm{C}\right)$, and then saturated in distilled water $(7$ days). Water content was determined by a gravimetric method after centrifuging the samples at $1000 \mathrm{~g}$ for $1 \mathrm{~h}$ at $10{ }^{\circ} \mathrm{C}$ in a laboratory centrifuge with a cooling unit. The results were recalculated to $100 \mathrm{~g}$ of absolutely dry weight. Water holding capacity index was calculated as a ratio of water content in a sample dried up to $105^{\circ} \mathrm{C}$ and in a sample of field-moisture. The state of secondary transformation of peat was 
evaluated according to the classification by Gawlik (2000): I - initially secondary transformed ( $\mathrm{W}_{1}$ : 0.36-0.45); II - weakly secondary transformed ( $\left.\mathrm{W}_{1}: 0.46-0.60\right)$; III - moderately secondary transformed ( $\mathrm{W}_{1}$ : 0.61-0.75); IV - strongly secondary transformed $\left(\mathrm{W}_{1}: 0.76-0.90\right) ; \mathrm{V}$ - completely degraded $\left(\mathrm{W}_{1}>0.90\right)$.

Water retention characteristics of the soil were determined using the equilibrium centrifuging method (Smagin and Prusak, 2008). Then, laboratory data were fitted with Van Genuchten model using the RETC computer program (Van Genuchten et al., 1991). These data were used to find out water retention capacity and differential porosity of the peat soil assuming that field water capacity (FWC) corresponded to $\theta_{\mathrm{v}}$ at $\mathrm{pF} 2.0$, available water retention (AWR) to $\theta_{\mathrm{v}}$ between $\mathrm{pF} 2.0$ and $\mathrm{pF} 4.2$, easily available water retention (EAWR) to $\theta_{\mathrm{v}}$ between $\mathrm{pF} 2.0$ and $\mathrm{pF} 2.7$ and small pore retention (SPR) to $\theta_{\mathrm{v}}$ between $\mathrm{pF} 2.7$ and $\mathrm{pF}$ 4.2. Macropore volume was calculated as a difference between total porosity and volumetric moisture content at $\mathrm{pF} 2.0$, mesopore volume was defined in the same way as AWR and micropore as volumetric moisture content at $\mathrm{pF}$ 4.2. Maximum hygroscopic moisture content was determined in a vacuum drying oven in the presence of saturated solution of $\mathrm{K}_{2} \mathrm{SO}_{4}$ (Mocek and Drzymała, 2010).

Soil ash content and $\mathrm{pH}$ analysis was performed in air dry samples as described by Sapek and Sapek (1997). Ash content was determined by a loss on ignition method where a peat sample $(2 \mathrm{~g})$ was incinerated in a muffle furnace at $550{ }^{\circ} \mathrm{C}$, and then calculated as difference between weight of the sample dried up at $105{ }^{\circ} \mathrm{C}$ and its weight after incineration. Soil $\mathrm{pH}$ and electric conductivity were determined in 1:10 (soil:solution) ratio. Soil $\mathrm{pH}$ was measured by a potentiometer in distilled water and in $1 \mathrm{M} \mathrm{KCl}$. The resulting values of electric conductivity were corrected for $\mathrm{H}^{+}$ions (Sjörs, 1950). Total carbon and nitrogen were determined on a CNS elemental analyzer. The samples were devoid of carbonates (inorganic carbon), and thus total carbon content corresponded to organic carbon content. These data were used to work out $\mathrm{C}: \mathrm{N}$ ratio. The content of ammonium nitrogen $\left(\mathrm{NH}_{4}{ }^{+}\right)$and nitrate nitrogen $\left(\mathrm{NO}_{3}{ }^{-}\right)$ was measured with a flow injection analysis method, and available phosphorus (P) was determined by Egner-Riehm method based on soil extraction with calcium lactate solution acidified with hydrochloric acid (Lityński et al., 1976).

\section{Vegetation}

At each study plot the percentage of cover by vascular plants and mosses was assessed. The bryophytes were determined to the genus level. Statistical analysis was based either on individual taxa or groups of species with similar habitat preferences. An analysis of effects of environmental factors on plant species occurrence (paper under review) demonstrated key importance of water level. Therefore, this paper analysed the vegetation pattern with regards only to chosen parameters affecting hydrological conditions of the soil surface. For the analyses vegetation was subdivided into groups: a) bog forming vegetation: Sphagnum, other bog species, b) non-bog forming vegetation: true mosses, trees (higher than $1.5 \mathrm{~m}$ ), other non-bog species.

\section{Statistical analysis}

Distribution of the determined soil parameters was verified with Shapiro-Wilk test $(p>0.05)$. As some variables did not follow a normal distribution, and the data 
transformation was ineffective, the non-parametric Spearman rank correlation coefficient was used to assess the interdependencies between them. Significance of differences in the analysed parameters of the two soil layers between both sectors was assessed using a parametric $t$ test for normal distribution variables, and nonparametric U-Mann Whitney test for non-normal distribution variables. The statistical analysis was performed in Statistica 12.

To compare the soil samples in terms of all investigated parameters and to estimate their relation to vegetation and environmental factors a multivariate statistical analysis method, i.e. Principal Component Analysis (PCA) was employed. It is a useful technique for identifying common patterns in data distribution that reduces the initial dimension of data sets and facilitates data interpretation. Ordination of all samples from $0-10 \mathrm{~cm}$ and $10-20 \mathrm{~cm}$ layers was based on eleven soil parameters (samples with negligible effect because of intercorrelations were excluded). The impact on vegetation was assessed with selected soil parameters (water-holding capacity index, volumetric moisture content, saturated moisture content, maximum hygroscopic moisture content, differential porosity) affecting hydrological conditions of the uppermost soil layer $(0-10 \mathrm{~cm})$. Since the soil parameters (variables) had different units, the data were centred and standardized to zero mean and unit variance before subjecting the data set to PCA. Residual peat thickness, water level and cover of vegetation were treated as passive variables not affecting the results of the ordination. Multivariate analysis was performed with Canoco software (ter Braak and Smilauer, 2002).

\section{Results}

When exploitation ceased on the younger Sector B, the site was covered with bog peat of cotton grass-Sphagnum (Eripohorum-Sphagnum) type with decomposition degree H4-6 as per Von Post scale. On Sector A harvesting exposed pine-Sphagnum peat (Pinus-Sphagnum) and sapric peat in which remains of pine wood were identified. One third of the study plots on this sector had a ca. $5 \mathrm{~cm}$ thick layer of compressed moss of decomposition degree $\mathrm{H} 4$ at a depth of approximately $5-6 \mathrm{~cm}$. On other study plots peat decomposition ranged from $\mathrm{H} 5$ to $\mathrm{H} 8$.

Sectors statistically differed mainly in physical and hydrophysical properties and some chemical properties. On Sector B there were more significant differences in parameters between the two investigated layers than on Sector A. The largest with-in site variability was noticed for chemical properties, such as ash content (especially in 10-20 cm layer), mineral nitrogen forms and corrected EC. The most variable physical and hydrophysical parameters included thickness of residual peat (Sector B) and volumetric water content (Sector A, $0-10 \mathrm{~cm}$ ). Low to moderate variability with a coefficient of variation usually below $30 \%$ was noticed for the other variables (Tables 1 and 2).

The soil water potential (pF)-moisture contents characteristic (Fig. 3) featured higher moisture content at FWC on older Sector A. Also, on this sector the volume of macropores was significantly lower (nearly two times) and that of micropores clearly higher, especially in 10-20 cm layer than on younger Sector B. In consequence, EAWR was higher on Sector B, while on Sector A more water was retained in smaller pores (SPR) (Table 3). In the layer 0-10 cm SPR represented $83 \%$ and $68 \%$ of AWR on Sectors A and B, respectively. 
Table 1. Statistical measures of the analyzed physical and hydrophysical parameters in the upper soil layer on Sectors $A$ and $B$

\begin{tabular}{|c|c|c|c|c|c|c|c|c|c|c|c|c|}
\hline \multirow{2}{*}{ Parameter } & \multirow{2}{*}{ Unit } & \multirow{2}{*}{$\begin{array}{c}\text { Layer } \\
{[\mathrm{cm}]}\end{array}$} & \multicolumn{2}{|c|}{ Min } & \multicolumn{2}{|c|}{ Max } & \multicolumn{2}{|c|}{ Mean } & \multicolumn{2}{|c|}{ SD } & \multicolumn{2}{|c|}{$\mathrm{V}[\%]$} \\
\hline & & & $\mathbf{A}$ & B & $\mathbf{A}$ & B & $\mathbf{A}$ & B & $\mathbf{A}$ & B & $\mathbf{A}$ & B \\
\hline \multirow{2}{*}{$\begin{array}{l}\text { Water-holding capacity } \\
\text { index } \mathrm{W}_{1}^{1,2,3,4}\end{array}$} & & & & & & & & & & & & \\
\hline & & & & & & & & 0.45 & & & & 17.41 \\
\hline \multirow{2}{*}{$\begin{array}{l}\text { Maximum hygroscopic } \\
\text { moisture content }{ }^{2,4}\end{array}$} & \multirow{2}{*}{ ol. $\%$} & & & & & 8.86 & & 16.72 & 521 & & & 25.71 \\
\hline & & & & & & & & & & & & 13.37 \\
\hline \multirow{2}{*}{$\begin{array}{l}\text { Volumetric moisture } \\
\text { content }{ }^{1,2,3,4}\end{array}$} & \multirow{2}{*}{ vol. \% } & & & 5 & 67 & 88 & 55 & 76.05 & 17. & 8.75 & & 11.50 \\
\hline & & & & & 89 & 90.43 & 76.94 & 83.45 & 7. & 7.85 & & 9.41 \\
\hline \multirow{2}{*}{$\begin{array}{l}\text { Saturated moisture } \\
\text { content } t^{1,2,3,4}\end{array}$} & \multirow{2}{*}{ vol. \% } & & & 7 & 90 & 85.69 & 3.00 & 81.86 & 7.14 & 3.06 & 9 & 3.73 \\
\hline & & & 41 & 76.80 & 91.37 & 92.58 & 83.06 & 87.18 & 4.49 & 3.99 & 5.41 & 4.58 \\
\hline \multirow{2}{*}{ Bulk density $^{2,4}$} & \multirow{2}{*}{$\mathrm{g} \mathrm{cm}^{-3}$} & & & 0.1 & 0.3 & 0.35 & 0.25 & 0.22 & 0.05 & 0.06 & & 25.07 \\
\hline & & & 0.2 & 0.1 & 0.3 & 0.31 & 0.21 & 0.16 & 0.07 & 0.05 & 33.06 & 29.27 \\
\hline \multirow{2}{*}{ Specific density ${ }^{3,4}$} & \multirow{2}{*}{$\mathrm{g} \mathrm{cm}^{-3}$} & & 1.5 & 1.47 & 1.7 & 1.78 & 1.59 & 1.57 & 0.06 & 0.10 & 4.02 & 6.59 \\
\hline & & & & 1. & & 1.93 & 1.61 & 1.52 & 0. & 0.10 & & 6.88 \\
\hline \multirow{2}{*}{ Total porosity ${ }^{1,2,3,4}$} & & & 21 & 77.02 & & 90 & 83.58 & 85.90 & 3.16 & 3.18 & 3.78 & 3.70 \\
\hline & & & 76.51 & 83.78 & 92.32 & 93.22 & 86.42 & 89.70 & 4.14 & 2.27 & 4.79 & 2.52 \\
\hline \multirow{2}{*}{$\begin{array}{c}\text { Volumetric } \\
\text { shrinkage }^{1,2,3,4}\end{array}$} & & & 15.75 & 19.14 & 53.12 & 59.93 & 31.68 & 45.07 & 9.07 & 10.40 & 28.63 & 23.08 \\
\hline & & & & & & 69.74 & 47.86 & 54.77 & 9.53 & 10.93 & 19.91 & 19.95 \\
\hline Peat thickness ${ }^{5}$ & $\mathrm{~cm}$ & - & 18.67 & 32.00 & 98.00 & 113.00 & 39.32 & 64.60 & 21.83 & 23.93 & 55.52 & 37.04 \\
\hline
\end{tabular}

$\mathrm{SD}$ - standard deviation; V- variability coefficient

${ }^{1}$ Statistically significant difference $(\mathrm{p}<0.05)$ in the layer $0-10 \mathrm{~cm}$ between Sectors A and B

${ }^{2}$ Statistically significant difference $(\mathrm{p}<0.05)$ in the layer $10-20 \mathrm{~cm}$ between Sectors A and B

${ }^{3}$ Statistically significant difference $(\mathrm{p}<0.05)$ between the layers $0-10 \mathrm{~cm}$ and $10-20 \mathrm{~cm}$ on Sector A

${ }^{4}$ Statistically significant difference $(\mathrm{p}<0.05)$ between the layers $0-10 \mathrm{~cm}$ and $10-20 \mathrm{~cm}$ on Sector B

${ }^{5}$ Statistically significant difference $(\mathrm{p}<0.001)$ between Sectors A and B

Table 2. Statistical measures of the analyzed chemical parameters in the upper soil layer on Sectors $A$ and $B$

\begin{tabular}{|c|c|c|c|c|c|c|c|c|c|c|c|c|}
\hline \multirow{2}{*}{ Parameter } & \multirow{2}{*}{ Unit } & \multirow{2}{*}{$\begin{array}{c}\text { Layer } \\
{[\mathrm{cm}]}\end{array}$} & \multicolumn{2}{|c|}{ Min } & \multicolumn{2}{|c|}{ Max } & \multicolumn{2}{|c|}{ Mean } & \multicolumn{2}{|c|}{ SD } & \multicolumn{2}{|c|}{$\mathrm{V}[\%]$} \\
\hline & & & $\mathbf{A}$ & $\mathbf{B}$ & $\mathbf{A}$ & $\mathbf{B}$ & $\mathbf{A}$ & $\mathbf{B}$ & $\mathbf{A}$ & $\mathbf{B}$ & $\mathbf{A}$ & $\mathbf{B}$ \\
\hline \multirow{2}{*}{ Ash content ${ }^{3,4}$} & & & & & & & & & 5.8 & & & 86.0 \\
\hline & & & & 1.40 & & 43.78 & 14.25 & 6.28 & 21.30 & 9.50 & 149.67 & 151.16 \\
\hline \multirow[b]{2}{*}{ ta } & & & & .19 & 2.02 & 2.02 & 1.70 & 1.65 & 0.17 & 0.21 & & 12.79 \\
\hline & & & .81 & 1.27 & 1.89 & 1.99 & 1.56 & 1.58 & 0.30 & 0.20 & 19.34 & 12.69 \\
\hline \multirow{2}{*}{ otal } & & & 47.45 & 33.84 & 58.14 & 63.07 & 53.79 & 55.57 & 2.81 & 6.71 & 5.22 & 12.08 \\
\hline & & -20 & 26.83 & 53.36 & 63.10 & 61.07 & 52.87 & 56.60 & 10.67 & 2.39 & 20.19 & 4.23 \\
\hline \multirow{2}{*}{$\mathrm{C}: \mathrm{N}$ ratio $^{2,3,4}$} & & & 24.36 & 26.75 & 39.37 & 48.34 & 31.85 & 33.96 & 3.60 & 4.55 & 11.29 & 13.40 \\
\hline & & $0-20$ & 29.87 & 29.05 & 37.84 & 42.24 & 33.97 & 36.38 & 2.09 & 4.28 & 6.15 & 11.78 \\
\hline $\mathrm{NO}$ & $\mathrm{kg}^{-1}$ & $0-10$ & 0.83 & 0.44 & 4.44 & 6.24 & 1.54 & 1.51 & 0.97 & 1.26 & 62.95 & 83.44 \\
\hline $\mathrm{NH}_{4}^{+1}$ & $\mathrm{~kg}^{-1}$ & $0-10$ & 7.68 & 35.84 & 44.58 & 172.46 & 16.19 & 77.54 & 9.03 & 33.79 & 55.74 & 43.58 \\
\hline Avai & $1-1$ & & 10.90 & 2.62 & 48.77 & 41.94 & 23.30 & 17.92 & 9.98 & 9.70 & 0.43 & 0.54 \\
\hline \multirow{2}{*}{$\mathrm{pH}_{\mathrm{H} 2 \mathrm{O}}^{1,2,4}$} & & 0 & 3.56 & 2.96 & 3.96 & 3.60 & 3.72 & 3.29 & 0.12 & 0.21 & 3.26 & 6.40 \\
\hline & & & 3.28 & 2.92 & 4.05 & 3.85 & 3.75 & 3.61 & 0.20 & 0.20 & 5.32 & 5.40 \\
\hline \multirow{2}{*}{$\mathrm{pH}_{\mathrm{KCl}}^{1,4}$} & & $\Omega_{0}$ & 2.35 & 2.52 & 3.24 & 2.90 & 2.82 & 2.68 & 0.23 & 0.13 & 8.12 & 4.86 \\
\hline & & & & 2.73 & 5.13 & 3.18 & 2.90 & 2.90 & 0.13 & 0.09 & 4.48 & 3.25 \\
\hline \multirow{2}{*}{$\begin{array}{l}\text { Corrected electric } \\
\text { conductivity } 1,2,3\end{array}$} & \multirow{2}{*}{$\mathrm{S} \mathrm{cm}^{-1}$} & $0-10$ & 119.00 & 60.62 & 252.08 & 264.00 & 177.77 & 134.58 & 38.34 & 50.35 & 21.57 & 37.41 \\
\hline & & $10-20$ & 115.08 & 61.73 & 381.36 & 220.36 & 245.30 & 113.47 & 61.08 & 44.93 & 24.90 & 39.60 \\
\hline
\end{tabular}

$\mathrm{SD}$ - standard deviation; V- variability coefficient

${ }^{1}$ Statistically significant difference $(\mathrm{p}<0.05)$ in the layer $0-10 \mathrm{~cm}$ between Sectors A and B

${ }^{2}$ Statistically significant difference $(\mathrm{p}<0.05)$ in the layer $10-20 \mathrm{~cm}$ between Sectors A and B

${ }^{3}$ Statistically significant difference $(\mathrm{p}<0.05)$ between the layers $0-10 \mathrm{~cm}$ and $10-20 \mathrm{~cm}$ on Sector A

${ }^{4}$ Statistically significant difference $(\mathrm{p}<0.05)$ between the layers $0-10 \mathrm{~cm}$ and $10-20 \mathrm{~cm}$ on Sector B

${ }^{5}$ Statistically significant difference $(\mathrm{p}<0.001)$ between Sectors A and B 
$\mathbf{a}$

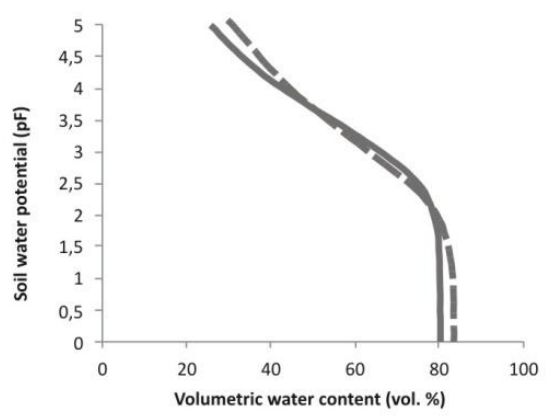

b

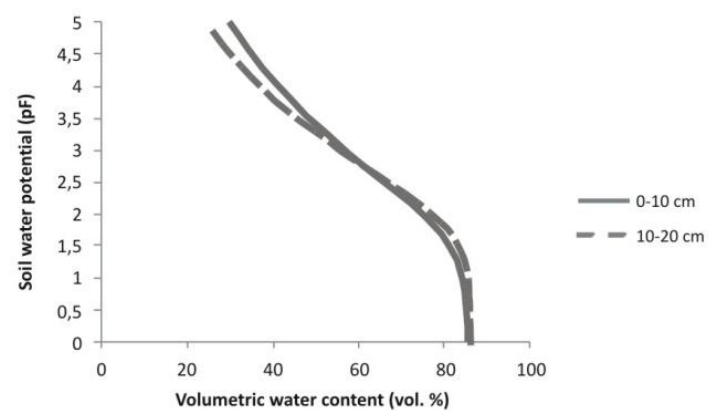

Figure 3. Water retention ( $p F$ curve) of the upper soil layer for Sectors $A(a)$ and $B(b)$

Table 3. Differential porosity and water retention characteristics in the upper soil layer on Sectors $A$ and $B$

\begin{tabular}{|c|c|c|c|c|c|c|c|c|}
\hline \multirow{2}{*}{ Parameter } & \multirow{2}{*}{ Unit } & \multirow{2}{*}{$\begin{array}{l}\text { Layer } \\
{[\mathrm{cm}]}\end{array}$} & \multicolumn{3}{|c|}{ A } & \multicolumn{3}{|c|}{ B } \\
\hline & & & Mean & SD & $\mathrm{V}[\%]$ & Mean & SD & $\mathrm{V}[\%]$ \\
\hline \multirow{2}{*}{$\begin{array}{c}\text { FWC } \\
(\mathrm{pF} 2.0)\end{array}$} & \multirow{2}{*}{ vol. \% } & $0-10$ & 78.42 & 6.01 & 13.05 & 74.60 & 8.22 & 9.08 \\
\hline & & $10-20$ & 78.08 & 7.33 & 10.66 & 74.91 & 9.60 & 7.81 \\
\hline \multirow{2}{*}{$\begin{array}{c}\mathrm{AWR}^{3} \\
(\mathrm{pF} 2.0-4.2)\end{array}$} & \multirow{2}{*}{ vol. \% } & $0-10$ & 39.71 & 5.44 & 7.30 & 36.56 & 7.50 & 4.74 \\
\hline & & $10-20$ & 37.71 & 10.46 & 3.61 & 44.88 & 10.23 & 4.39 \\
\hline \multirow{2}{*}{$\begin{array}{c}\text { EAWR }^{1} \\
(\mathrm{pF} 2.0-2.7)\end{array}$} & \multirow{2}{*}{ vol. $\%$} & $0-10$ & 6.77 & 3.39 & 1.20 & 11.35 & 3.43 & 3.31 \\
\hline & & $10-20$ & 7.39 & 3.95 & 1.87 & 9.33 & 4.87 & 1.91 \\
\hline \multirow{2}{*}{$\begin{array}{c}\mathrm{SPR}^{1,3} \\
(\mathrm{pF} 2.7-4.2)\end{array}$} & \multirow{2}{*}{ vol. \% } & $0-10$ & 32.94 & 5.88 & 5.60 & 24.21 & 6.25 & 3.88 \\
\hline & & $10-20$ & 30.32 & 12.24 & 2.48 & 35.55 & 14.36 & 2.48 \\
\hline \multirow{2}{*}{$\begin{array}{l}\text { Micropores }^{2,3} \\
(\mathrm{pF} 4.2)\end{array}$} & \multirow{2}{*}{$\%$} & $0-10$ & 38.71 & 9.05 & 4.28 & 39.03 & 6.87 & 7.56 \\
\hline & & $10-20$ & 40.37 & 7.41 & 5.45 & 30.04 & 3.71 & 8.10 \\
\hline \multirow{2}{*}{ Macropores $^{1}$} & \multirow{2}{*}{$\%$} & $0-10$ & 5.16 & 7.41 & 0.70 & 11.30 & 8.33 & 1.36 \\
\hline & & 10-20 & 9.11 & 7.18 & 1.27 & 14.79 & 9.70 & 1.53 \\
\hline
\end{tabular}

Explanations: FWC - field water capacity; AWR - available water retention $=$ mesopores; EAWR easily available water retention; SPR - smaller pores retention; SD - standard deviation; V - variability coefficient

${ }^{1}$ Statistically significant difference $(\mathrm{p}<0.05)$ in the layer $0-10 \mathrm{~cm}$ between Sectors A and B ${ }^{2}$ Statistically significant difference $(\mathrm{p}<0.05)$ in the layer $10-20 \mathrm{~cm}$ between Sectors A and B

${ }^{3}$ Statistically significant difference $(\mathrm{p}<0.05)$ between the layers $0-10 \mathrm{~cm}$ and $10-20 \mathrm{~cm}$ on Sector B

Water-holding capacity index $\mathrm{W}_{1}$ for the majority, i.e. $57 \%$ of analysed samples ranged between 0.46 and 0.60 (weakly secondary transformed), for $22 \%$ of samples it was $0.61-0.75$ (moderately secondary transformed), and for $17 \%$ of samples between 0.36 and 0.45 (initially secondary transformed). Mean values of $\mathrm{W}_{1}$ in the layers 0 $10 \mathrm{~cm}$ and $10-20 \mathrm{~cm}$ (Table 1) indicated moderate to weak secondary transformation of peat mass on Sector A, while on Sector B it was weak to initial. There was a strong positive correlation of the $\mathrm{W}_{1}$ index with bulk density and ash content (consequently with specific density), and a negative correlation with total porosity, volumetric shrinkage and soil moisture content. Moderate correlation was observed with thickness 
of residual peat, total $\mathrm{C}, \mathrm{C}: \mathrm{N}$ ratio, and $\mathrm{pH}$. The $\mathrm{W}_{1}$ index least strongly correlated with the content of micro- and mesopores and corrected EC (Table 4).

Table 4. Spearman's rank correlation between water-holding capacity index $W_{1}$ and analyzed soil parameters. The statistically significant $(p<0.05)$ values of correlation coefficient (Rho) are marked in bold

\begin{tabular}{c|c}
\hline Parameter & Rho \\
\hline Total porosity & $\mathbf{- 0 . 6 5 3}$ \\
Bulk density & $\mathbf{0 . 6 3 7}$ \\
Volumetric moisture content & $\mathbf{- 0 . 6 3 1}$ \\
Saturated moisture content & $\mathbf{- 0 . 5 9 7}$ \\
Ash content & $\mathbf{0 . 5 8 6}$ \\
Volumetric shrinkage & $\mathbf{- 0 . 5 4 1}$ \\
Peat thickness & $\mathbf{- 0 . 4 7 4}$ \\
Total C & $\mathbf{- 0 . 4 2 3}$ \\
C:N ratio & $\mathbf{- 0 . 3 9 4}$ \\
pH & $\mathbf{0 . 3 4 8}$ \\
Corrected electric conductivity & $\mathbf{0 . 2 9 5}$ \\
Micropores & $\mathbf{0 . 2 8 4}$ \\
$\mathrm{NH}_{4}{ }^{+1}$ & -0.285 \\
Mesopores (AWR) & $\mathbf{- 0 . 2 4 9}$ \\
Macropores $^{\mathrm{NO}_{3}{ }^{-1}}$ & $\mathbf{0 . 2 3 2}$ \\
Available $\mathrm{P}^{1}$ & -0.224 \\
& 0.140 \\
\hline
\end{tabular}

${ }^{1} 0-10 \mathrm{~cm}$ layer only

In PCA of all soil samples (both sectors and layers) (Fig. 4), the first PCA axis explained $45.3 \%$ and the second $12.4 \%$ of total variance. Water level and residual peat thickness most strongly correlated with the first PCA axis. Dispersion of soil samples was higher on Sector A than on Sector B. The samples were arranged from those from the older Sector A, layer 0-10 cm (left-hand part of the diagram), to those from the younger Sector B, layer 10-20 cm (right-hand part of the diagram). The samples from Sector A, layer 10-20 cm and Sector B layer 0-10 cm occupied a common central area of the diagram. Single samples deviated from this trend. There was a significant $(\mathrm{p}<0.05)$ negative correlation $(\mathrm{r}=-0.771)$ between residual peat thickness and water level. In general, an increase of peat thickness and water table level was associated with a decrease in bulk density, water-holding capacity index $\mathrm{W}_{1}$, maximum hygroscopic moisture content and total $\mathrm{N}$ and an increase in total porosity, macropore volume, soil moisture content, volumetric shrinkage, $\mathrm{pH}$, total $\mathrm{C}$ and $\mathrm{C}: \mathrm{N}$ ratio. Contrary to that, micropore volume, ash content and corrected EC were increasing with depth on the older Sector A but decreasing on the younger one. 


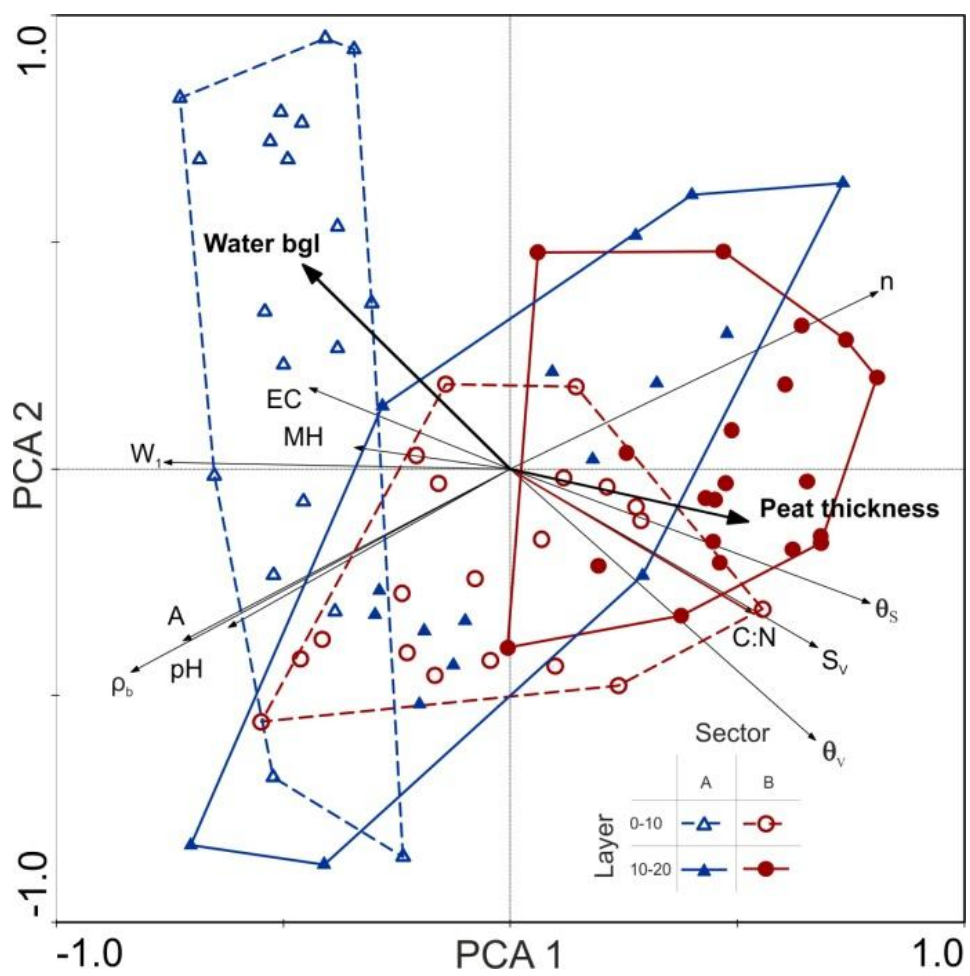

Figure 4. Result of PCA ordination conducted on soil parameters of all samples. Abbreviations: $W_{l}$ - water-holding capacity index, $\mathrm{MH}$ - maximum hygroscopic moisture content, $\theta_{v}-$ volumetric moisture content, $\theta_{s}-$ saturated moisture content, $\rho_{b}-$ bulk density, $n$-total porosity, $S_{v}$ - volumetric shrinkage, A - ash content, C:N-total nitrogen and total carbon ratio, EC-corrected electric conductivity, Water bgl-mean water level below ground.

Environmental factors (Peat thickness, Water $\mathrm{bgl}$ ) are displayed as passive variables

Typical bog-forming species occurred on all plots (Table 5). Mosses of the Sphagnum genus, which are the main bog forming plants, were found only on $44 \%$ of the plots and did not achieve a large coverage. Among the bog forming vascular plants the most frequent (97\%) and of the largest cover (on average 36\%) was Eriophorum vaginatum. Trees exceeding $1.5 \mathrm{~m}$ were found on the majority of the plots $(82 \%)$, sometimes reaching high cover (up to 60\%), especially on the older Sector A (Fig. 5). These were mainly Betula pendula and Pinus sylvestris. Small trees (up to $1.5 \mathrm{~m}$ ) appeared with a relatively high frequency. However their share in the area cover was small. Calluna vulgaris, Vaccinium myrtillus and V. vitis-idea were among the most common other non-bog forming species. Very few minerotrophic species were recorded more than once (Empetrum nigrum, Juncus effusus, Sorbus aucuparia, Carex nigra, Eriophorum angustifolium, Dryopteris carthusiana). The most frequent was Dryopteris carthusiana with frequency $11 \%$.

In PCA ordination based on the parameters affecting hydrological conditions (Fig. 5) the first axis explained $34.7 \%$, and the second $30.1 \%$ of total variance. Water level, residual peat thickness and vegetation most strongly correlated with the second axis. Typical bog forming vegetation was clearly concentrated in the lower part of the diagram, opposite to the non-bog forming vegetation. Especially cover of Sphagnum was associated with studied plots showing lower $\mathrm{W}_{1}$ index, higher water level, peat thickness, soil moisture content and macropores volume. 
Table 5. Frequency of occurrence [\%] and cover [\%] of plant groups (in bold) and species. Mean cover is calculated only for plots on which the species was present. In the group of other non-bog species only the species with frequency $>30 \%$ are presented

\begin{tabular}{c|c|c|c|c|c}
\hline & \multicolumn{3}{|c|}{ Cover } & \multirow{2}{*}{ Frequency } \\
\cline { 2 - 4 } & Min & Max & Mean & \\
\hline Bog forming vegetation \\
\hline Other bog species & 1 & 30 & 9 & 44 \\
Eriophorum vaginatum & $\mathbf{5}$ & $\mathbf{9 5}$ & $\mathbf{2 1}$ & $\mathbf{1 0 0}$ \\
Vaccinium uliginosum & 0 & 95 & 36 & 97 \\
Ledum palustre & 0 & 50 & 15 & 82 \\
Oxycoccus palustris & 0 & 25 & 6 & 67 \\
\hline \multicolumn{5}{c}{ Non-bog forming vegetation } \\
True mosses & $\mathbf{0}$ & $\mathbf{5 7}$ & $\mathbf{2 2}$ & 18 \\
\hline Trees (higher than 1.5 m) & $\mathbf{3}$ & $\mathbf{6 0}$ & $\mathbf{2 0}$ & $\mathbf{9 5}$ \\
Other non-bog species & $\mathbf{0}$ & $\mathbf{3 0}$ & $\mathbf{1 0}$ & $\mathbf{9 2}$ \\
Calluna vulgaris & 0 & 60 & 20 & 82 \\
Vaccinium vitis-idaea & 0 & 45 & 11 & 41 \\
Vaccinium myrtillus & 0 & 25 & 6 & 44 \\
Betula pendula & 0 & 5 & 2 & 44 \\
Pinus sylvestris & 0 & 5 & 1 & 59 \\
\hline
\end{tabular}

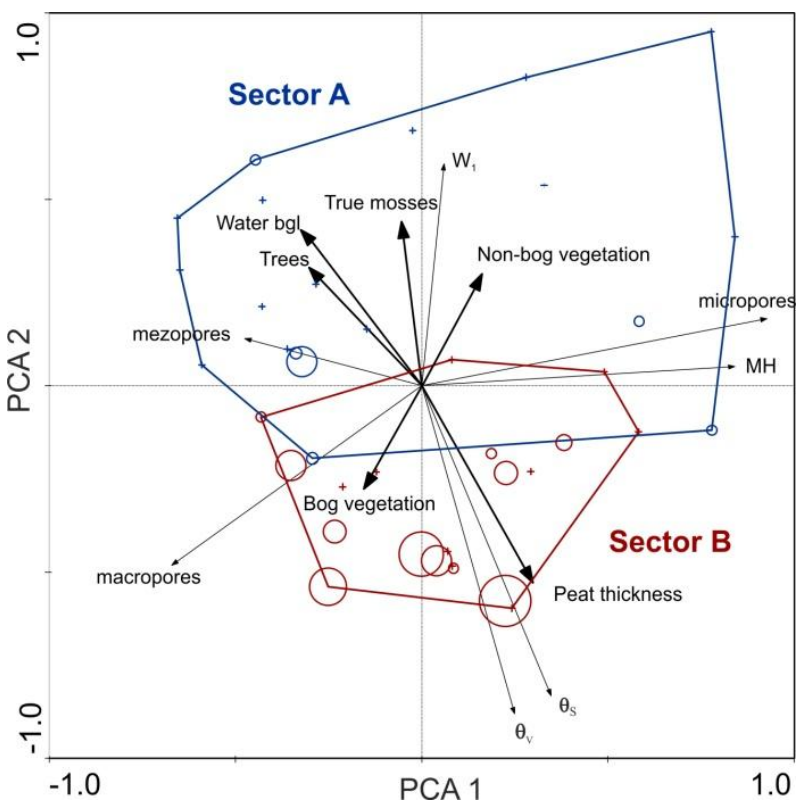

Figure 5. Result of PCA ordination conducted on chosen parameters affecting hydrological conditions of surface peat layer $(0-10 \mathrm{~cm})$. Abbreviations: $W_{1}-$ water-holding capacity index, $M H$ - maximum hygroscopic moisture content, $\theta_{v}$-volumetric moisture content, $\theta_{s}-$ saturated moisture content, Water bgl-mean water level below ground. Environmental factors (Peat thickness, Water bgl) and vegetation cover are displayed as passive variables. Circle diameter is proportional to Sphagnum cover of plot, + depict plots with no Sphagnum 


\section{Discussion}

Post-extracted areas of peatlands are divers mainly in terms of characteristics of the exposed peat (type, degree of decomposition, thickness), drainage intensity, climatic conditions, as well as the re-vegetation pattern. That is why making direct comparisons of hydrological conditions and soil properties of cut-over peat with other sites is difficult. However, there are some distinct trends in secondary transformations of analysed peat soil. The study indicated that the changes in a bog peat were similar to that observed in minerotrophic fens (e.g. Ilnicki and Zeitz, 2003).

The longer time after abandonment of post-extracted areas without any treatments e.g. drainage blocking, the more advanced secondary transformation of peat, reaching deeper layers. Differences in physical and hydrophysical soil properties of examined sites were essential as compared with fibric material (e.g. Boelter, 1969) of the uppermost (acrotelm) layer of a natural bog. An increase in $\mathrm{pH}$, electric conductivity and mineral forms of nitrogen $\left(\mathrm{NO}_{3}{ }^{-}, \mathrm{NH}_{4}{ }^{+}\right)$at peat surface was recorded, as on other post-extracted areas (Wind-Mulder et al., 1996), but overall it remained acidic and poor in nutrients. We used water holding capacity index $\mathrm{W}_{1}$ as a quantitative indicator of secondary transformation of cut-over bog. The correlations stated between $\mathrm{W}_{1}$ index and the range of analysed soil properties were similar to those reported in other studies, mainly for fens (Gawlik, 1993, 1996; Szajdak et al., 2000; Boguta and Sokołowska, 2014; Glina et al., 2016). This suggests that water-holding capacity index $\mathrm{W}_{1}$ can be a valuable measure reflecting the degree of peat soil degradation on post-extracted areas, which is manifested primarily in changes of soil hydrophysical conditions.

We observed strong correlation between parameters affecting water conditions of surface peat, i.e. water level, residual peat thickness, soil moisture, pore sizes and waterholding capacity index $\mathrm{W}_{1}$ and establishment of different vegetation groups (bog forming and non-bog forming). In time, peat substrate quality created more unfavourable hydrophysical conditions for re-vegetation by typical bog species, especially Sphagnum what was evidenced in multivariate analysis (older vs. younger sector). However, to be more specific the state of secondary transformation of peat depends more on soil water conditions after drainage than the time that elapsed since drainage (Gawlik, 1996).

Hydrophysical conditions of the peatland surface are considered the main variable affecting Sphagnum growth (e.g. Price and Whitehead, 2001). Peat (catotelm) that was exposed after ceasing peat extraction on investigated site maintained high water retention capacity but water was retained with high pressure. Similar results were reported for other post-extracted sites (Schlotzhauer and Price, 1999; Mustamo et al., 2016). High water retention capacity results from the moderate to high decomposition degree of the peat matrix, hence high fraction of small pores (e.g. Boelter, 1969). Increase in bulk density due to peat consolidation and further decay in drainage conditions subsequently alter size of pore spaces (e.g. Whittington and Price, 2006). Hence increased peat decomposition and soil compaction result in a decrease in easily available water retention and a rise in smaller pores retention (Gawlik, 1992).

Macropore volume in analysed soil was comparable with specific yield reported by Price (1996) or Mustamo et al. (2016) on post-extracted sites, as well as with the water yield coefficient (which represents the same area on $\mathrm{pF}$ curve as macropores and is an equivalent of specific yield) given by Boelter (1969) for sapric peat. Their percentage was very low compared to slightly decomposed Sphagnum peat (Verry et al., 2011). Low macropores volume and specific yield may seriously inhibit Sphagnum 
development as unlike vascular plants it is unable to uptake water from the substrate when pore-water pressure is lower than $-100 \mathrm{mb}$ (Hayward and Clymo, 1982 after Price, 1997). According to Price and Whitehead (2001), hydrological conditions suitable for Sphagnum recovery require high water table level $(24.9 \pm 14.3 \mathrm{~cm})$, volumetric moisture content above $50 \%$, and pore-water pressure above $-100 \mathrm{mb}$. However, if volume of small pores is high, water is held at such low pressure that it cannot be drawn by Sphagnum through capillary suction (Price et al., 2003). Furthermore, Dixon et al. (2017), who studied moss water availability demonstrated that both factors, deeper profile and shallower starting water table, delayed the beginning of very high surface tension and that peat deposits shallower than $0.5 \mathrm{~m}$ showed the lowest capability of equalizing prolonged periods of evaporative stress.

The cited studies are consistent with our results that indicated better conditions for establishment of bog forming vegetation, especially Sphagnum on areas with thicker residual peat layer, shallower water table, higher soil moisture content and macropore volume. On such areas surface peat layer was less secondary transformed. This was expressed in lower $\mathrm{W}_{1}$ index, which indirectly denoted lower density of peat, hence higher porosity. Hydrophysical properties of the uppermost layer of cut-over peat are particularly important to Sphagnum as they lack roots and vascular channels (Schouwenaars and Gosen, 2007) and unlike vascular plants they cannot take up water from deeper layers of soil. On the contrary, non-bog forming vegetation (mainly true mosses and trees) developed better on drier conditions, when peat layer was thin and secondary transformation of peat expressed as $\mathrm{W}_{1}$ index, more advanced. Increased share of true mosses, like Polytrichum associated with lowered water level was described by Potvin et al. (2015). Dry conditions also facilitate tree seedling establishment, as Sphagnum growth is then impeded (Limpens et al., 2014). In humid climatic conditions of Central Europe woodland is a typical potential vegetation (Ellenberg and Leuschner, 2010), so trees occupy abandoned post-extracted peatlands over time. Trees strongly affect peatland ecosystems through changes in the structure and species composition, availability of light and soil physical and chemical properties (Mitchell et al., 2007). Trees (Van Seters and Price, 2001) and also ericaceaous shrubs (Farrick and Price, 2009) increase peat drying by interception of precipitation water and transpiration, which especially in birch is high (Fay and Lavoie, 2009). Therefore, they may further exacerbate secondary transformation of peat.

It is important that restoration should begin directly after extracted area is abandoned (Price, 1997). Only then it can be possible to mitigate effects of drainage and consequently changes in peat structure and properties as well as to inhibit establishment of trees.

\section{Conclusions}

The properties of the peat surface deteriorate on abandoned cut-over bogs, where peat dries up over time. The process can be also exacerbated by vascular vegetation, especially trees. Secondary transformation of peat may be comprehensively described by water-holding capacity index $\mathrm{W}_{1}$. It correlates with thickness of residual peat and a range of properties of cut-over peat (e.g. porosity, bulk density, soil moisture content, ash content), that change as the degradation advances. Identification of these correlations means that $\mathrm{W}_{1}$ index may be used in evaluation of secondary transformation of peat mass on cut-over bogs. 
The study demonstrated the key importance of water table depth, residual peat thickness and hydrophysical conditions of the cut-over peat surface, especially waterholding capacity index $\mathrm{W}_{1}$, soil moisture content and macropore volume on revegetation of Sphagnum. Negative correlation of $\mathrm{W}_{1}$ index with Sphagnum occurrence indicates that it may also be a useful measure in evaluation of the potential of cut-over bogs for spontaneous regeneration of typical bog vegetation, mainly Sphagnum species. Implementation of such approach into practice requires further research on other degraded bogs for verification.

Our study suggests that prospective restoration strategy of post-extracted areas should consider implications of unfavourable physical properties of the cut-over peat surface on hydrological conditions. However, any solutions aimed at providing appropriate hydrological conditions must be site-specific due to huge diversity of local conditions (e.g. Gorham and Rochefort, 2003; Price et al., 2003; Shantz and Price, 2006).

Acknowledgments. We thank to the authorities of Gmina Czarny Duanjec, especially Michał Jarończyk and Bogusław Sroka from Peat Production Plant "Bór za Lasem" in Czarny Dunajec for help and permission to conduct the research. We also thank to Ewa Zagrodzka and Marek Turschmid for assistance in the field and laboratory work. This research was carried out within Projects DS-3331/KMIKŚ and DS3337/KEKiOP financed from a research grant allocated by the Polish Ministry of Science and Higher Education.

\section{REFERENCES}

[1] Boelter, D. H. (1969): Physical properties of peats as related to degree of decomposition. - Soil Science Society of America Proceedings 33: 606-609.

[2] Boguta, P., Sokołowska, Z. (2014): Statistical relationship between selected physicochemical properties of peaty-muck soils and their fraction of humic acids. International Agrophysics 28: 269-278.

[3] Bragg, O., Lindsay, R. (eds.) (2003): Strategy and Action Plan for Mire and Peatland Conservation in Central Europe. - Wetlands International, Wageningen, The Netherlands.

[4] Couwenberg, J. (2011): Greenhouse gas emissions from managed peat soils: is the IPCC reporting guidance realistic? - Mires and Peat 8: 1-10.

[5] Dixon, S. J., Kettridge, N., Moore, P. A., Devito, K. J., Tilak, A. S., Petrone, R. M., Mendoza, C. A., Weddington, J. M. (2017): Peat depth as a control on moss water availability under evaporative stress. - Hydrological Processes 31: 4107-4121.

[6] Eggelsmann, R. (1986): Subsidence of Peatland Caused by Drainage, Evaporation and Oxidation. - In: Johnson, A. I., Carbognin, L., Ubertini, L. (eds.) Land Subsidence: Proceedings of the Third International Symposium on Land Subsidence Held in Venice, Italy, 19-25 March 1984. - IAHS Publication No. 151, Institute of Hydrology, Wallingford, Oxfordshire, UK, pp. 497-505.

[7] Ellenberg, H., Leuschner, C. (2010): Vegetation of Central Europe and the Alps in an Ecological, Dynamic and Historical Perspective. - Ulmer Verlag, Stuttgart (in German).

[8] Farrick, K. K., Price, J. S. (2009): Ericaceous shrubs on abandoned block-cut peatlands: Implications for soil water availability and Sphagnum restoration. - Ecohydrology 2: 530-540.

[9] Fay, E., Lavoie, C. (2009): The impact of birch seedlings on evapotranspiration from a mined peatland: an experimental study in southern Quebec, Canada. - Mires and Peat 5: $1-7$. 
[10] Gawlik, J. (1992): Water holding capacity of peat formations as an index of the state of their secondary transformation. - Polish Journal of Soil Science 25: 121-126.

[11] Gawlik, J. (1993): An attempt to evaluate changes in the water retainability of peatsoils in the context of their advancing degradation. - Polish Journal of Soil Science 26: 82-86.

[12] Gawlik, J. (1996): The usefulness of water holding capacity index for evaluation of the state of secondary transformation of the peat soils. - Wiadomości IMUZ 28: 197-216 (in Polish).

[13] Gawlik, J. (2000): Division of differently silted peat formations into classes according to their state of secondary transformation. - Acta Agrophysica 26: 17-24.

[14] Glina, B., Bogacz, A., Gulyás, M., Zawieja, B., Gajewski, P., Kaczmarek, Z. (2016): The effect of long-term forestry drainage on the current state of peatland soils: A case study from the Central Sudetes, SW Poland. - Mires and Peat 18: 1-11.

[15] Glińska-Lewczuk, K., Burandt, P., Łaźniewska, I., Łaźniewski, J., Menderski, S., Pisarek, W. (2014): Conservation and Restoration of Raised Bogs in Gązwa, Zielony Mechacz and Soltysek Nature Reserves in Northern Poland. - Polskie Towarzystwo Ochrony Ptaków, Białowieża (in Polish).

[16] Gorham, E., Rochefort, L. (2003): Peatland restoration: A brief assessment with special reference to Sphagnum bogs. - Wetlands Ecology and Management 11: 109-119.

[17] Hayward, P. M., Clymo, R. S. (1982). Profiles of water content and pore size in Sphagnum peat and their relation to peat bog ecology. - Proceedings of the Royal Society of London B215: 299-325.

[18] Herbichowa, M., Pawlaczyk, P., Stańko, R. (2007): Conservation of Baltic raised bogs in Pomerania. Poland experience and results of the LIFE04NAT/PL/000208 PLBALTBOGS Project). - Wydawnictwo Klubu Przyrodników Świebodzin (in Polish).

[19] Hufnagel, L., Garamvölgyi, Á. (2014): Impacts of climate change on vegetation distribution no. 2 - climate change induced vegetation shifts in the new world. - Applied Ecology and Environmental Research 12(2): 355-422.

[20] Ilnicki, P. (2002): Peatlands and Peat. - Wydawnictwo Akademii Rolniczej w Poznaniu (in Polish).

[21] Ilnicki, P., Zeitz, J. (2003): Irreversible loss of organic soil functions after reclamation. In: Parent, L.-E., Ilnicki, P. (eds.) Organic Soils and Peat Materials for Sustainable Agriculture, CRC Press LLC, Boca Raton, FL, USA, pp. 15-32.

[22] Joosten, H., Clarke, D. (2002): Wise use of Mires and Peatlands - Background and Principles Including a Framework for Decision-Making. - International Mire Conservation Group/International Peat Society, Saarijärvi, Finland.

[23] Joosten, J. H. J. (1992): Bog Regeneration in The Netherlands: A Review. - In: Bragg, O. M., Hulme, P. D., Ingram, H. A. P. Roberstson, R. A. (eds.) Peatland Ecosystems and Man: An Impact Assessment. British Ecological Society/International Peat Society, Dundee, pp. 367-373.

[24] Kac, N. J., Kac, S. W., Skobiejewa, E. (1977): Atlas of Plant Remains in Peat Soil. Nedra, Moskwa (in Russian).

[25] Kalisz, B., Lachacz, A., Glazewski, R. (2015): Effects of peat drainage on labile organic carbon and water repellency in NE Poland. - Turkish Journal of Agriculture and Forestry 39: 20-27.

[26] Kondracki, J. (2011): Regional geography of Poland. - Wydawnictwo Naukowe PWN, Warszawa (in Polish).

[27] Krüger, J. P., Leifeld, J., Glatzel, S., Szidat, S., Alewell, C. (2015): Biogeochemical indicators of peatland degradation - a case study of a temperate bog in northern Germany. - Biogeosciences 12: 2861-287.

[28] Łajczak, A. (2006): Peat bogs of the Orawsko-Nowotarska Basin. Development, Human Impact, Renaturalisation and Selected Problems of Protection. - Wydawnictwo Instytutu Botaniki PAN, Kraków (in Polish). 
[29] Laine, M. P. P., Strömmer, R., Arvola, L. (2013): Nitrogen release in pristine and drained peat profiles in response to water table fluctuations: A mesocosm experiment. - Applied and Environmental Soil Science 2013: 1-7.

[30] Limpens, J., van Egmond, E., Li, B., Holmgren, M. (2014): Do plant traits explain tree seedling survival in bogs? - Functional Ecology 28: 283-290.

[31] Lipka, K., Zając, E. (2014): Stratigraphy of Peatlands in the Orawa-Nowy Targ Basin. Wydawnictwo Art-Tekst, Kraków (in Polish).

[32] Lityński, T., Jurkowska, H., Gorlach, E. (1976): Chemical and Agricultural Analysis. Wydawnictwo Naukowe PWN, Warszawa (in Polish).

[33] Mitchell, R. J., Campbell, C. D., Chapman, S. J., Osler, G. H. R., Vanbergen, A. J., Ross, L. C., Cameron, C. M., Cole, L. (2007): The cascading effects of birch on heathe moorland: a test for the top-down control of an ecosystem engineer. - Journal of Ecology 95: 540-554.

[34] Mocek, A., Drzymała, S. (2010): Genesis, analysis and classification of soils. Wydawnictwo WUP Poznań (in Polish).

[35] Mustamo, P., Hyvärinen, M., Ronkanen, A.-K., Kløve, B. (2016): Physical properties of peat soils under different land use options. - Soil Use and Management 32: 400-410.

[36] Okruszko, H. (1971): Determination of Specific Density of Hydrogenic Soils Based on Mineral Particels Content. - Wiadomości IMUZ 52: 7-54 (in Polish).

[37] Okruszko, T., Mioduszewski, W., Kucharski, L. (eds). (2011): Conservation and Restoration of Wetlands of Kampinos National Park. - Wydawnictwo SGGW, Warszawa (in Polish).

[38] Olszewski, K. (1988): Climatic Conditions of the Orawsko-Nowotarskie Peatlands. - In: Primary Documentation of the Planned Orawsko-Nowotarskie Peatlands Landscape Park. Ms. Wydział Geografii i Studiów Regionalnych, Uniwersytet Warszawski (in Polish).

[39] Parent, L. E., Ilnicki, P. (eds.) (2003): Organic Soils and Peat Materials for Sustainable Agriculture. - CRC Press LLC, Boca Raton, FL, USA.

[40] Potvin, L. R., Kane, E. S., Chimner, R. A., Kolka, R. K., Lilleskov, E. A. (2015): Effects of water table position and plant functional group on plant community, aboveground production, and peat properties in a peatland mesocosm experiment (PEATcosm). - Plant Soil 387: 277-294.

[41] Price, J. S. (1996): Hydrology and microclimate of a partly restored cutover bog, Quebec. - Hydrological Processes 10: 1263-1272.

[42] Price, J. S. (1997): Soil moisture, water tension, and water table relationships in a managed cutover bog. - Journal of Hydrology 202: 21-32.

[43] Price, J. S., Whitehead, G. S. (2001): Developing hydrologic thresholds for Sphagnum recolonization on an abandoned cutover bog. - Wetlands 21: 32-40.

[44] Price, J. S., Heathwaite, A. L., Baird, A. J. (2003): Hydrological processes in abandoned and restored peatlands: An overview of management approaches. - Wetlands Ecology and Management 11: 65-85.

[45] Sapek, A., Sapek, B. (1997): Methods for Chemical Analysis of Organic Soils. Materiały Instruktażowe 115, Wydawnictwo IMUZ, Falenty (in Polish).

[46] Schlotzhauer, S. M., Price, J. S. (1999): Soil water flow dynamics in a managed cutover peat field, Quebec: Field and laboratory investigations. - Water Resources Research 35: 3675-3683.

[47] Schouwenaars, J. M. (1993): Hydrological differences between bogs and bog relicts and consequences for bog restoration. - Hydrobiologia 265: 217-224.

[48] Schouwenaars, J. M., Gosen, A. M. (2007): The sensitivity of Sphagnum to surface layer conditions in a re-wetted bog: a simulation study of water stress. - Mires and Peat 2: 119.

[49] Shantz, M. A., Price, J. S. (2006): Hydrological changes following restoration of the Bois-des-Bel Peatland, Quebec, 1992-2002. - Journal of Hydrology 331: 543-553. 
[50] Sjörs, H. (1950): On the relation between vegetation and electrolytes in north Swedish mire waters. - Oikos 2: 241-58.

[51] Smagin, A. V., Prusak, A. V. (2008): The effect of earthworm coprolites on the soil water retention curve. - Eurasian Soil Science 41: 618-622.

[52] Sokołowska, Z., Szajdak, L., Matyka-Sarzyńska, D. (2005): Impact of the degree of secondary transformation on acid-base properties of organic compounds in mucks. Geoderma 127: 80-90.

[53] Szajdak, L., Matuszewska, T., Gawlik, J. (2000): The dependence of total and hydrophobic amino acids content upon secondary transformation state of peat-muck soils. - Wiadomości IMUZ 20: 75-90 (in Polish).

[54] Szuflicki, M., Malon, A., Tymiński, M. (eds.) (2017): Balance Sheet of Mineral Resources in Poland as at 31.XII.2016. - Państwowy Instytut Geologiczny-Państwowy Instytut Badawczy, Warszawa (in Polish).

[55] ter Braak, C. J. F., Smilauer, P. (2002): Canoco Reference manual and CanoDraw for Windows Users Guide: Software for Canonical Community Ordination (version 45). Microcomputer Power, Ithaca NY USA.

[56] Tobolski, K. (2000): A guide for the Determination of Peat and Lake Sediments. Wydawnictwo Naukowe PWN, Warszawa (in Polish).

[57] Van Genuchten, M.T., Leij, F. J., Yates, S. R. (1991): The RECT code for quantifying the hydraulic functions of unsaturated soils. - EPA/600/2-91/065.

[58] Van Seters, T. E., Price, J. S. (2001): The impact of peat harvesting and natural regeneration on the water balance of an abandoned cutover bog, Quebec. - Hydrological Processes 15: 233-248.

[59] Verry, E. S., D. H. Boelter, J. Paivanen, D. S. Nichols, Malterer, T., Gafni, A. (2011): Physical properties of Organic Soils. - In: Kolka, R.K, Sebestyen, S. S., Verry, E. S., Brooks, K. N. (eds.) Peatland Biogeochemistry and Watershed Hydrology at the Marcell Experimental Forest. CRC Press, Boca Raton, FL., pp. 135-176.

[60] Von Post, L. (1924): Genetic Classification for the Organic Soils of Sweden. - Comité Intemational de Pédologie IV, Communication 22: 287-304 (in German).

[61] Waddington, J. M., Rotenberg, P. A., Warren, F. J. (2001): Peat $\mathrm{CO}_{2}$ production in a natural and cutover peatland: implications for restoration. - Biogeochemistry 54: 115130.

[62] Whittington, P. N., Price, J. S. (2006): The effects of water table draw-down (as a surrogate for climate change) on the hydrology of a fen peatland, Canada. - Hydrological Processes 20: 3589-3600.

[63] Wind-Mulder, H. L., Vitt, D. H. (2000): Comparisons of water and peat chemistries of a post-harvested and undisturbed peatland with relevance to restoration. - Wetlands 20: 4: 616-628.

[64] Wind-Mulder, H. L., Rochefort, L., Vitt, D. H. (1996): Water and peat chemistry comparisons of natural and post-harvested peatlands across Canada and their relevance to peatland restoration. - Ecological Engineering 7: 161-181. 